\title{
Gotowość do złożenia zawiadomienia o popełnieniu przestępstwa w kontekście sytuacji psychologicznej osoby pokrzywdzonej
}

\author{
BARBARA LEŚNIAK \\ ORCID: 0000-0002-1204-0988 \\ Instytut Psychologii Uniwersytetu Śląskiego w Katowicach \\ MAREK LEŚNIAK \\ ORCID: 0000-0002-5049-7225 \\ Instytut Prawa Uniwersytetu Śląskiego w Katowicach
}

\section{Wstęp}

$\mathrm{W}$ procesie stosowania prawa zagadnienia $\mathrm{z}$ dwóch odmiennych ontologicznie zakresów - normatywnego oraz deskryptywnego (obszaru ustaleń faktycznych) — wzajemnie się przenikają. Dzieje się tak również w wypadku problematyki gotowości do złożenia zawiadomienia o popełnieniu czynu zabronionego przez osobę pokrzywdzoną. Z jednej strony obowiązujące regulacje prawne częściowo determinują sytuację ofiary przestępstwa (wprost odnoszą się do tej sytuacji albo wpływają na nią poprzez kształtowanie zachowań innych uczestników postępowania karnego wobec niej), stwarzają określone możliwości działania albo kwalifikują niektóre jej zachowania jako przedmiot obowiązku. Z drugiej strony przewidziane prawem działania decydenta procesowego wymagają dokonania określonych ustaleń faktycznych. Ich efektywność, a także 
ocena etyczna zależą niekiedy od odtworzenia sytuacji psychologicznej ofiary przestępstwa. Dlatego też w opinii autorów uzasadnione jest poświęcenie odpowiedniej uwagi problematyce gotowości ofiary przestępstwa do podjęcia decyzji o złożeniu zawiadomienia z uwzględnieniem jej sytuacji psychologicznej. Odpowiednie w tym zakresie rozeznanie pozwala funkcjonariuszom organów ścigania oraz pracownikom organów wymiaru sprawiedliwości na zmniejszenie oporu ofiar czynu zabronionego wobec zgłoszenia ich zaistnienia oraz wobec złożenia pełnej relacji odnośnie do przebiegu zdarzenia, jak również zmniejsza ryzyko przyczynienia się do wiktymizacji lub wtórnej wiktymizacji (zapobiega niewłaściwemu traktowaniu ofiary).

Celem autorów jest zatem przedstawienie znaczenia ustalenia sytuacji psychologicznej osoby pokrzywdzonej przestępstwem w procesie stosowania prawa, w szczególności w kontekście gotowości do zgłaszania faktu bycia ofiarą przestępstwa. Zostaną jednocześnie uwzględnione aspekty związane z wiktymizacją wtórną. Adekwatnie do postawionego celu w poszczególnych częściach wywodu zostaną zaprezentowane następujące kwestie: elementy sytuacji psychologicznej (z uwzględnieniem procesów decyzyjnych), prawne aspekty sytuacji ofiar przestępstw, raporty na temat sytuacji osób pokrzywdzonych przestępstwem w Polsce, istniejące bariery w zakresie składania zawiadomienia o popełnieniu przestępstwa.

W kontekście dalszego wywodu należy uściślić kwestie terminologiczne. W świetle artykułu $49 \S 1$ ustawy z dnia 6 czerwca 1997 roku Kodeks postępowania karnego (dalej: k.p.k.) ${ }^{1}$ pokrzywdzonym jest osoba fizyczna lub prawna, której dobro prawne zostało bezpośrednio naruszone lub zagrożone przez przestępstwo. Pokrzywdzonym mogą być również instytucje oraz jednostki wymienione w art. 49 § 2 i 3 k.p.k. W dalszych wywodach nazwa „osoba pokrzywdzona” (,pokrzywdzony") będzie zawężona w stosunku do języka prawnego i będzie używana wyłącznie odnośnie do osób fizycznych zamiennie z określeniem „ofiara przestępstwa” („ofiara”). Takie ujęcie uzasadnione jest podjętą problematyką, sytuacja psychologiczna jest sytuacją człowieka. W wypadku czynów zabronionych popełnionych wobec osób prawnych, instytucji

${ }^{1}$ Tekst jedn. Dz.U. 2018.1987. 
i innych jednostek organizacyjnych również konkretne osoby związane z tymi jednostkami znajdują się w określonej sytuacji psychologicznej, ale kwestię tę zostawiamy poza zakresem naszych rozważań.

\section{Istota sytuacji psychologicznej ofiary przestępstwa}

Według koncepcji „człowieka w sytuacji” T. Tomaszewskiego sytuacja „obejmuje elementy otoczenia człowieka wraz z nim samym, takie, jakimi one są obiektywnie i w obiektywnych stosunkach wzajemnych, i takie, jakimi je spostrzegają ludzie uczestniczący w tej sytuacji (nie tylko sam podmiot sytuacji)"2. Autor wyróżnił dwa podstawowe dla sytuacji zachowania człowieka, reaktywne i celowe, adekwatne odpowiednio do struktury stymulacyjnej sytuacji oraz zadaniowej ${ }^{3}$. Reaktywne łączą się z działającymi jako bodźce elementami sytuacji, a celowe z rozumieniem sytuacji jako układu wartości i możliwości. W kontekście zachowania ofiary czynu zabronionego istotne jest odróżnienie wartości i możliwości obiektywnych oraz subiektywnych ${ }^{4}$. Ocena obiektywna wiąże się ze spojrzeniem na sytuację konkretnego człowieka z zewnątrz, opisem i oceną jego położenia niezależnie od tego, jak on sam je postrzega. Człowiek w sytuacji odbiera z kolei swoją sytuację subiektywnie, opisuje i nadaje znaczenie poszczególnym jej elementom przez pryzmat indywidualnego doświadczenia oraz własnych cech psychologicznych (cech osobowości, systemu wartości, stanu emocjonalnego itp.). Obiektywnie ta sama sytuacja może zatem być odbierana przez uczestniczące w niej osoby zupełnie inaczej.

Tomaszewski odróżnia między innymi sytuacje normalne od sytuacji trudnych ${ }^{5}$. Sytuację normalną cechuje równowaga jej elementów oraz powtarzalność; sytuacja trudna pojawia się, gdy równowaga ta zostaje zakłócona. Występuje pięć głównych rodzajów sytuacji trudnych: deprywacji (podmiot traci coś, czego potrzebuje do normalnego funkcjonowania), przeciążenia (stopień komplikacji jest na granicy możli-

2 T. Tomaszewski, Czlowiek i otoczenie, [w:] Psychologia, red. T. Tomaszewski, Warszawa 1979, s. 22.

${ }^{3}$ Ibidem, s. 22 n.

${ }^{4}$ Ibidem, s. 26 n.

${ }^{5}$ Ibidem, s. 32 n. 
wości fizycznych, umysłowych i emocjonalnych podmiotu), utrudnienia (realizacja normalnych zadań jest ograniczona wskutek pojawienia się nowych zbędnych elementów albo utraty potrzebnych elementów), konfliktowa (na podmiot działają przeciwstawne siły, na przykład fizyczne, moralne, społeczne), zagrożenia (zwiększa się ryzyko naruszenia wartości cenionej przez podmiot, na przykład zdrowia lub życia podmiotu lub osób bliskich, własności czy posiadania, pozycji społecznej, dobrego imienia, poziomu samooceny). Wspomniane rodzaje sytuacji trudnych, jak podkreśla T. Tomaszewski, nie tylko nie wykluczają się wzajemnie, lecz współwystępują, a nawet są od siebie zależne.

Warto podkreślić, że opisana koncepcja jest akceptowana przez polskich psychologów; W. Łukaszewski zauważa, że „,W literaturze trudno znaleźć pomysły równie inspirujące jak teoretyczna propozycja Tadeusza Tomaszewskiego i - mimo swojej prostoty — równie kompletne" ${ }^{\text {. }}$

$\mathrm{Na}$ podstawie opisanych cech sytuacji psychologicznej w kontekście sytuacji ofiary konkretnego czynu zabronionego należy odróżnić obiektywną sytuację (elementy sytuacji mogą być wspólne dla wielu podobnych zdarzeń) od subiektywnego postrzegania sytuacji przez ofiarę. Funkcjonowanie ofiary jest zdeterminowane przede wszystkim jej subiektywną percepcją wszystkich aspektów zdarzenia (między innymi przyczyn, przebiegu, skutków, kontekstu); subiektywna percepcja w kontekście cech osobowości i własnych doświadczeń determinuje sytuację psychologiczną ofiary, która może być różna nawet wśród ofiar tego samego rodzaju czy tego samego konkretnego czynu zabronionego. Rodzi to konieczność indywidualnego podejścia funkcjonariuszy organów ścigania oraz pracowników wymiaru sprawiedliwości do ofiar przestępstwa. Bycie ofiarą czynu zabronionego z reguły wiąże się ze znalezieniem się w trudnej sytuacji psychologicznej; jest możliwe współwystępowanie każdego z wymienionych rodzajów sytuacji trudnych. W tym aspekcie pojawienie się określonego rodzaju sytuacji trudnej może zależeć nie tylko od rodzaju czynu zabronionego i rozmiarów skutków, sposobu działania i cech sprawcy tego czynu, ale od subiektywnej percepcji sytuacji przez osobę pokrzywdzoną.

${ }^{6}$ W. Łukaszewski, Koncepcje sytuacji trudnych: krok naprzód czy krok wstecz, „Czasopismo Psychologiczne — Psychological Journal” 21, 2015, s. 38. 
W kontekście postępowania $\mathrm{z}$ ofiarami czynów zabronionych wymagane są zatem dwa uzupełniające się podejścia:

— dążenie do standaryzacji zachowań pracowników wymiaru sprawiedliwości i funkcjonariuszy odpowiednich służb wobec ofiar czynów zabronionych (nie ma standardów — nie ma błędów, standardy wymuszają pewne zachowania wobec ofiar przestępstwa);

— dążenie do zindywidualizowanego podejścia do osoby składającej zawiadomienie o popełnieniu przestępstwa, konieczność rozpoznania jej sytuacji psychologicznej i traktowania adekwatnie do tego rozpoznania.

Jeszcze raz warto podkreślić, że wyróżnione dążenia nie są przeciwstawne, ale uzupełniają się nawzajem. Połączenie zaprezentowanych dążeń może być przedstawione jako objęcie standardami postępowania wobec ofiary czynu zabronionego, ustalenie jej sytuacji psychologicznej (połączonej z subiektywnym spostrzeganiem swojej sytuacji w związku z czynem zabronionym), a następnie dostosowanie zachowań funkcjonariuszy organów ścigania i pracowników wymiaru sprawiedliwości do ustalonej sytuacji psychologicznej.

Ustalenie sytuacji psychologicznej ofiary przestępstwa wymaga oczywiście odpowiedniego przygotowania; funkcjonariusze organów ścigania oraz pracownicy wymiaru sprawiedliwości powinni przejść w tym zakresie odpowiednie szkolenia. Zapewne niektóre kategorie ofiar lub sytuacji będą wymagały skorzystania z wiedzy i umiejętności psychologa.

\section{Prawny aspekt sytuacji osób pokrzywdzonych}

W kontekście podjętej problematyki należy omówić wybrane regulacje prawne, najistotniejsze z punktu widzenia sytuacji psychologicznej osoby pokrzywdzonej.

Jak stanowi art. 234 ustawy z dnia 6 czerwca 1997 roku Kodeks karny $^{7}$ (dalej: k.k.),

kto przed organem powołanym do ścigania lub orzekania w sprawach o przestępstwo, w tym i przestępstwo skarbowe, wykroczenie, wykroczenie skarbowe lub przewinienie dyscyplinarne, fałszywie oskarża inną osobę o popełnienie tych czynów zabronionych

7 Tekst jedn. Dz.U. 2019.1950. 
lub przewinienia dyscyplinarnego, podlega grzywnie, karze ograniczenia wolności albo pozbawienia wolności do lat 2 .

Niezbędną przesłanką odpowiedzialności za przedmiotowe przestępstwo jest intencjonalne działanie sprawcy. Nie ma więc odpowiedzialności w wypadku błędu osoby pokrzywdzonej (na przykład rozpoznaniu w trakcie okazania jako sprawcy niewłaściwej osoby) lub jej działaniu pod wpływem objawów zaburzeń psychicznych (urojeń albo omamów).

W postępowaniu karnym pokrzywdzony może wystąpić albo w roli strony, albo wyłącznie świadka. Bycie stroną pozwala na czynny udział w postępowaniu karnym, między innymi w: czynnościach procesowych (poza ustawowymi ograniczeniami), składaniu zażaleń na decyzje organów procesowych (a także wniesieniu apelacji od wyroku), składaniu oświadczeń i wniosków dowodowych, korzystaniu z bezpłatnej pomocy tłumacza (gdy pokrzywdzony nie zna języka polskiego, ewentualnie gdy jest głuchy lub niemy), zapoznawaniu się z opiniami biegłych, dostępie do akt sprawy. W postępowaniu przygotowawczym pokrzywdzony jest stroną niezależnie od swoich działań (art. 299 § 1 k.p.k.), w postępowaniu przed sądem jest stroną (oskarżycielem posiłkowym), gdy złoży odpowiedni wniosek do czasu rozpoczęcia przewodu sądowego (art. 53 i 54 § 1 k.p.k.). Jeśli pokrzywdzony nie złoży wniosku o przystąpienie do postępowania w charakterze oskarżyciela posiłkowego, jest wyłącznie świadkiem (aczkolwiek o poszerzonych w stosunku do innych świadków uprawnieniach); będąc stroną postępowania, również składa zeznania jako świadek. Pokrzywdzony i najbliższe mu osoby mogą otrzymać bezpłatną pomoc medyczną, psychologiczną, prawną oraz materialną ze środków Funduszu Pomocy Pokrzywdzonym (art. 43 § 8 pkt 1 ustawy z dnia 6 czerwca Kodeks karny wykonawczy ${ }^{8}$, dalej: k.k.w.). Informacje na temat miejsca zamieszkania oraz miejsca pracy pokrzywdzonego nie są ujawniane w aktach sprawy (art. 148a k.p.k.). Okazanie z udziałem pokrzywdzonego można przeprowadzić w sposób uniemożliwiający rozpoznanie przez osoby rozpoznawane (art. $173 \S 2$ k.p.k.). Pokrzywdzony może być przesłuchany w miejscu jego pobytu (jeśli nie może się stawić wskutek ,choroby, kalectwa lub innej niedającej się pokonać przeszkody”, art. 177 § 3 k.p.k.) lub z użyciem urządzeń technicznych przekazują-

${ }^{8}$ Tekst jedn. Dz.U. 2019.676. 
cych obraz i dźwięk na odległość (art. 177 § 3). W celu minimalizowania ryzyka wtórnej wiktymizacji ustawodawca zapewnił szczególną ochronę przesłuchiwanym jako świadkom pokrzywdzonym małoletnim, którzy nie ukończyli 15. roku życia (art. 185a § 1-3 k.p.k.) oraz małoletnim, którzy ukończyli 15 lat (art. 185a § 4 k.p.k.). Niemałoletnim pokrzywdzonym (którzy ukończyli 18 lat) podobna ochrona jest przewidziana tylko w wypadku nielicznych przestępstw (opisanych w artykułach 197199 k.k.); w sprawach tych składane przez pokrzywdzonego zawiadomienie powinno ograniczyć się do najważniejszych faktów i dowodów (art. 185c k.p.k.).

Na pokrzywdzonego nałożono również wiele obowiązków. Jest on między innymi zobowiązany stawić się na każde wezwanie organu procesowego (art. 177 § 1 k.p.k.). W sytuacji gdy karalność czynu zależy od jego stanu zdrowia, nie może sprzeciwić się „oględzinom i badaniom niepołączonym z zabiegiem chirurgicznym lub obserwacją w zakładzie leczniczym" (192 § 1 k.p.k.), a w razie zaistnienia wątpliwości odnośnie do stanu rozwoju umysłowego, zdolności postrzegania lub odtwarzania spostrzeżeń, jak każdy inny świadek, pomimo nieudzielenia zgody, może zostać przesłuchany z udziałem biegłego lekarza lub biegłego psychologa" (art. 192 § 2 k.p.k.). W wypadku uchybienia obowiązkom stawienia się na wezwanie organu procesowego lub pozostawania do jego dyspozycji także na pokrzywdzonego może zostać nałożona kara porządkowa (art. $285 \S 1$ k.p.k.), jak również może w stosunku do niego zostać zarządzone zatrzymanie i przymusowe doprowadzenie (art. 285 § 2 k.p.k.). W wypadku pokrzywdzonego, który nie jest stroną (a więc nie występuje jako oskarżyciel posiłkowy w postępowaniu sądowym), jak również nie jest osobą, która może uchylić się od zeznawania (osobą najbliższą dla oskarżonego). Tego rodzaju środki i kary mogą być zarządzone, gdy uchyla się od złożenia zeznania, złożenia przyrzeczenia lub nie spełnia innego ciążącego na nim obowiązku (art. $287 \S 1 \mathrm{w}$ związku z art. 287 $\S 4$ k.p.k.); w razie uporczywości tego rodzaju zachowania jest możliwe aresztowanie na czas do $30 \mathrm{dni}$ (art. 287 §). W literaturze przedmiotu zwraca się uwagę na ostateczność stosowania tego rodzaju środków wobec pokrzywdzonych ${ }^{9}$, niemniej jest to prawnie dopuszczalne. W takich

9 R. Koper, Stosowanie aresztowania wobec świadka w procesie karnym, „Prokuratura i Prawo" 2014, nr 5, s. 13 n. 
sytuacjach organ procesowy szczególnie powinien ustalić subiektywną sytuację psychologiczną pokrzywdzonego; nie powinien kierować się wyłącznie zewnętrznymi symptomami, w szczególności zachowaniem świadka, kwalifikując je na przykład jako „uporczywe”.

Zgodnie z art. $233 \S 1$ k.k. świadek zeznający nieprawdę lub zatajający prawdę podlega karze pozbawienia wolności od 6 miesięcy do 8 lat; jeśli świadek czyni tak w obawie przed odpowiedzialnością karną grożącą jemu lub jego najbliższym, kara ta mieści się w przedziale od 3 miesięcy do 5 lat. Jednocześnie świadek może uchylić się od odpowiedzi na pytanie, jeżeli mogłoby to narazić jego lub osobę mu najbliższą na odpowiedzialność za przestępstwo (art. $183 \S 1$ k.p.k.). Realizując uprawnienia z art. $183 \S 1$, świadek może zwrócić uwagę organu procesowego na okoliczności, których nie chciał ujawnić ${ }^{10}$. Konieczną przesłanką odpowiedzialności świadka z art. 233 k.k. jest uprzednie odpowiednie pouczenie zeznającego lub odebranie przyrzeczenia (art. $233 \S 2$ i 3 k.k.). W świetle wyników badań psychologicznych takie pouczenie paradoksalnie może mieć negatywny wpływ na jakość zeznań świadka ${ }^{11}$.

Dnia 25 października 2012 roku została przyjęta dyrektywa Parlamentu Europejskiego i Rady 2012/29/UE ustanawiająca normy minimalne w zakresie praw, wsparcia i ochrony ofiar przestępstw ${ }^{12}$ (dalej: dyrektywa). W myśl art. 1a (i) i (ii) ofiarą przestępstwa jest „osoba, która doznała szkody, w tym krzywdy fizycznej, psychicznej, moralnej lub emocjonalnej lub straty majątkowej, bezpośrednio spowodowanej przestępstwem”, jak również „członkowie rodziny osoby, której śmierć była bezpośrednim skutkiem przestępstwa, jeżeli doznali oni szkody w wyniku śmierci tej osoby". Odnośnie do praw ofiary przestępstwa ujętych w dyrektywie zwraca się uwagę na konieczność indywidualizacji zachowań pracowników instytucji państwa wobec konkretnej ofiary czynu zabronionego. Normy zawarte w dyrektywie określają standardy

10 M. Mozgawa, Glosa do uchwaty Sądu Najwyższego z dnia 20 września 2007 r. sygn. I KZP 26/07, „Prokuratura i Prawo” 2007, nr 12, s. 159-160.

11 M. Szpitalak, R. Polczyk, Czy ostrzė̇enie może szkodzić? Wptyw ostrzė̇enia na jakość zeznań świadka, „Z Zagadnień Nauk Sądowych” 86, 2011, s. 149-150.

12 https://eur-lex.europa.eu/legal-content/PL/TXT/?uri=CELEX\%3A32012L0029 (dostęp: 30.09.2019). 
minimalne $\mathrm{w}$ postępowaniu $\mathrm{z}$ ofiarami przestępstw. Jednym $\mathrm{z}$ nich jest indywidualizacja podejścia do ofiary przestępstwa.

Można wskazać różne regulacje mające znaczenie w kontekście sytuacji psychologicznej ofiary:

- $\mathrm{w}$ ramach prawa do rozumienia i bycia rozumianym (art. 3 dyrektywy) zwraca się uwagę na pomoc ofiarom w „rozumieniu i byciu rozumianym od momentu pierwszego kontaktu z właściwym organem i podczas jakichkolwiek dalszych niezbędnych kontaktów z nimi w ramach postępowania karnego, również w przypadku udzielenia informacji przez te organy"; przy przekazywaniu informacji ofiarom „uwzględnia się cechy osobowe ofiary, w tym wszelkie rodzaje niepełnosprawności, które mogą mieć wpływ na zdolność ofiary do rozumienia lub bycia rozumianym";

— w ramach prawa do otrzymywania informacji (art. 5 dyrektywy) podkreśla się, że zakres i szczegółowość wymienionych w tym artykule informacji mogą być zróżnicowane między innymi w zależności od „szczegółowych potrzeb i osobistych uwarunkowań ofiary”;

- zakres prawa do korzystania z usług służb udzielających wsparcia ofiarom ma być stosowny do potrzeb ofiary i nie może być uzależniony od złożenia przez ofiarę oficjalnego zawiadomienia o popełnieniu przestępstwa;

— w ramach prawa do wsparcia ze strony służb udzielających wsparcia ofiarom przestępstw (art. 9) ofiara ma prawo między innymi do „wsparcia emocjonalnego, gdy jest dostępne, wsparcia psychologicznego”, jak również do „doradztwa dotyczącego zagrożenia wtórną i ponowną wiktymizacją, zastraszaniem oraz odwetem i sposobów zapobiegania tym zjawiskom";

— w ramach prawa do ochrony (art. 18) zapewnia się „dostępność środków służących ochronie ofiar i członków ich rodzin przed wtórną i ponowną wiktymizacją, zastraszaniem oraz odwetem - w tym także środków przeciwko ryzyku szkód, emocjonalnych lub psychologicznych, oraz służących ochronie godności ofiar podczas przesłuchania lub składania zeznań";

- ofiara ma prawo do unikania kontaktu ze sprawcą (art. 19);

- w ramach praw do ochrony ofiar w trakcie postępowania przygotowawczego (art. 20) zwraca się uwagę na zapewnienie (,,bez uszczerbku 
dla praw do obrony i zgodnie z przepisami o swobodzie sędziowskiej”) między innymi tego, żeby ,,przesłuchania ofiar zostały przeprowadzone bez zbędnej zwłoki po złożeniu właściwemu organowi zawiadomienia o popełnieniu przestępstwa”, a „liczba przesłuchań była jak najbardziej ograniczona", a przesłuchania przeprowadzane, ,gdy jest absolutnie niezbędne do celów postępowania przygotowawczego");

— ofiara ma prawo do ochrony prywatności (art. 21).

W kontekście sytuacji psychologicznej ofiary przestępstwa znaczenie ma przewidziana w dyrektywie ,indywidualna ocena służąca ustaleniu szczególnych potrzeb ofiar w zakresie ochrony" (art. 22), a służąca stosowaniu środków przewidzianych w art. 23 i 24 dyrektywy. Ocena ta uwzględnia w szczególności: cechy osobowe ofiar, rodzaj lub charakter przestępstwa oraz jego okoliczności; w jej ramach

szczególną uwagę zwraca się na ofiary, które doznały znacznej szkody ze względu na powagę przestępstwa, ofiary przestępstw popełnionych z powodu uprzedzeń lub dyskryminacji — co mogło być w szczególności powiązane z ich cechami osobowymi — oraz ofiary, których szczególne narażenie jest skutkiem związku ze sprawcą lub zależności od niego.

Dyrektywa nakazuje w tym zakresie uwzględniać „ofiary terroryzmu, przestępczości zorganizowanej, handlu ludźmi, przemocy na tle płciowym, przemocy w bliskich związkach, przemocy seksualnej lub wykorzystywania seksualnego lub przestępstw z nienawiści oraz ofiary będące osobami niepełnosprawnymi”. Wśród środków ochrony dyrektywa wspomina między innymi o: przesłuchaniach ofiar przez te same osoby (w wypadku wielu przesłuchań), w specjalnych pomieszczeniach, przez lub z udziałem specjalistów, w wypadku niektórych kategorii czynów przez osoby tej samej płci, za pomocą środków zapewniających unikanie kontaktu wzrokowego między ofiarą a sprawcą, w sposób umożliwiający unikanie zbędnych pytań dotyczących życia prywatnego ofiar niezwiązanych z przestępstwem. Bycie dzieckiem (osoba, która nie ukończyła 18. roku życia) uzasadnia stosowanie wobec ofiary szczególnych środków ochrony. Państwa członkowskie powinny zapewniać osobom pracującym z ofiarami odpowiednie szkolenia (art. 25),

by urzędnicy, którzy mogą mieć kontakt $\mathrm{z}$ ofiarami, tacy jak funkcjonariusze policji i pracownicy sądu, przeszli zarówno ogólne, jak i specjalistyczne szkolenie na poziomie odpowiadającym ich kontaktom z ofiarami, mające uświadamiać im potrzeby ofiar oraz nauczyć ich traktowania ofiar z szacunkiem oraz w sposób bezstronny, i profesjonalny. 
Regulacje przedmiotowej dyrektywy zostały w znacznej części implementowane do polskiego systemu prawnego, w szczególności w drodze ustawy z dnia 28 listopada 2014 roku o ochronie i pomocy dla pokrzywdzonego i świadka ${ }^{13}$. Ustawa ta nie tylko opisuje rodzaje środków ochrony pokrzywdzonego, określa tryb i przesłanki ich stosowania, lecz wprowadza także wiele zmian do k.p.k., k.k.w.

Rzecznik Praw Obywatelskich w swoim wystąpieniu do ministra sprawiedliwości i prokuratora generalnego (XI.518.39.2017) ${ }^{14} 17$ listopada 2017 roku podniósł niewywiązanie się przez Polskę z określonego w art. 27 ust. 1 dyrektywy obowiązku wprowadzenia w życie przez państwa członkowskie do 16 listopada 2015 roku przepisów ustawowych, wykonawczych i administracyjnych, niezbędnych do wykonania dyrektywy. Rzecznik praw obywatelskich zwrócił między innymi uwagę, że podstawowym celem dyrektywy jest realizacja indywidualnych potrzeb ofiar przestępstwa oraz wzmocnienie praw ofiar;

przy dokonywaniu oceny potrzeb osoby pokrzywdzonej przestępstwem należy brać pod uwagę takie cechy osobowe ofiary jak wiek, płeć oraz tożsamość płciowa, pochodzenie etniczne, rasa, religia, orientacja seksualna, stan zdrowia, niepełnosprawność, ale także status pobytowy, problemy z komunikacją, związek ze sprawcą lub zależność od niego, doświadczenie przestępstwa w przeszłości.

Rzecznik zwraca uwagę, że w przepisach implementujących ustawę nie wskazano wprost na cechy osobowe ofiar przestępstw.

Prawne środki istotne $\mathrm{z}$ punktu widzenia ofiary przestępstwa są zawarte również w ustawie z dnia 29 lipca 2005 roku o przeciwdziałaniu przemocy w rodzinie ${ }^{15}$. Ofiarom tego rodzaju przestępczości (art. 3 pkt 1) udziela się bezpłatnej pomocy, między innymi w zakresie: poradnictwa medycznego, psychologicznego, prawnego, socjalnego, zawodowego i rodzinnego), interwencji kryzysowej i wsparcia, ochrony przed dalszym krzywdzeniem (uniemożliwienie korzystania ze wspólnie zajmowanego z ofiarami mieszkania oraz zakazanie kontaktowania się i zbliżania się do

13 Dz.U. 2015.21.

14 https://www.rpo.gov.pl/sites/default/files/Wyst\%C4\%85pienie $\% 20$ do $\% 20$ MS\%20w\%20sprawie\%20implementacji\%20dyrektywy\%20ofiarowej\%2010.08.2017. pdf (dostęp: 30.09.2019).

15 Tekst jedn. Dz.U.2015.1390. 
ofiar), zapewnienia bezpiecznego schronienia w specjalistycznym ośrodku wsparcia dla ofiar przemocy w rodzinie.

\section{Postępowanie wobec osób pokrzywdzonych w świetle raportów}

W polskiej literaturze przedmiotu można znaleźć stosunkowo niewiele aktualnych opracowań na temat sytuacji osób pokrzywdzonych przestępstwem $\mathrm{w}$ Polsce. W tym kontekście warto przytoczyć treść dwóch raportów. Pierwszy z nich dotyczy wybranych grup osób pokrzywdzonych przestępstwem i wybranych rodzajów przestępstw, drugi zaś ilustruje możliwość wiktymizacji wtórnej w wypadku pokrzywdzonych występujących w charakterze świadków w sądzie.

W opublikowanym w 2018 roku raporcie z Badania charakteru i skali niezgłaszanych przestęstw z nienawiści wobec członków wybranych spoteczności w Polsce (przeprowadzonego w pierwszym półroczu 2018 roku), przygotowanego na zlecenie Biura Instytucji Demokratycznych i Praw Człowieka OBWE (ODHiR) oraz Biuro Rzecznika Praw Obywatelskich $\mathrm{RP}^{16}$, stwierdzono, że tylko w $3 \%$ przypadków przestępstwa z nienawiści zostały zgłoszone policji przez ofiarę (badaniami objęte były trzy grupy: Ukraińcy, muzułmanie oraz osoby z Afryki Subsaharyjskiej, łącznie 643 osób); w 2\% przypadków przestępstwo zostało zgłoszone przez inną osobę (a więc $95 \%$ przypadków zakwalifikowanych przez osoby prowadzące badanie jako przestępstwo z nienawiści nie zgłoszono odpowiedniemu organowi). Uwzględniając wszystkie przestępstwa, których ofiarami byli respondenci badania w latach 2016, 2017 (269 czynów), należy stwierdzić, że tylko 19 (około 7\%) zostało zgłoszonych (w tym zakresie raport nie różnicuje, ile z nich zgłosiły same ofiary).

Głównym powodem złożenia zawiadomienia o popełnieniu przestępstwa (90\% zgłoszeń miało postać formalnych zawiadomień) była chęć powiadomienia organów ścigania o przestępstwach, które dotykają znacznej populacji imigrantów. Zgłaszający oczekiwali, że policja potraktuje te czyny tak samo jak inne czyny zagrożone karą, a sprawca zostanie zatrzymany i ukarany. Niestety organizatorzy nie poszerzyli badań w kon-

16 https://www.osce.org/pl/odihr/412463?download=true (dostęp: 30.09.2019). 
tekście zachowań funkcjonariuszy policji względem osoby zgłaszającej. Uwzględniono jedynie, czy policja zapytała o motywację sprawcy (w $42 \%$ wypadków funkcjonariusz nie pytał osoby pokrzywdzonej o motywację sprawcy) oraz czy uznała, że przestępstwo było związane z uprzedzeniami. Natomiast przyczynami niezgłoszenia faktu bycia ofiarą przestępstwa najczęściej były: uznanie przestępstwa za błahe, niewarte zgłoszenia ( $26 \%$ ofiar, które nie zgłosiły przestępstwa), brak pewności, czy policja będzie mogła coś poradzić (22\%), załatwienie sprawy we własnym zakresie lub z pomocą przyjaciół, krewnych (22\%), uznanie, że nie było żadnych dowodów $(21 \%)$. Stosunkowo niewiele osób podało takie powody, jak: poczucie zagrożenia ze strony sprawców (9\%), ocena relacji zgłaszającego jako niewiarygodnej (8\%), obawy przed rasistowską albo ksenofobiczną reakcją policji (7\%), trudności językowe, komunikacyjne (4\%). Tylko jeden uczestnik badania obawiał się, że utraci pozwolenie na stały pobyt. Można podejrzewać, że badania objęły wyłącznie osoby legalnie przebywające lub pracujące w Polsce. Uzasadnione są spekulacje, że odsetek zgłaszających bycie ofiarą przestępstwa wśród osób nielegalnie przebywających w Polsce byłby jeszcze niższy.

W analizowanych badaniach $32 \%$ ofiar nie mogło złożyć skargi w znanym im języku, nie mogły więc również zostać odpowiednio pouczone o prawach ofiary. W kontekście wsparcia udzielonego ofiarom odnotowano, że następujący odsetek ofiar był poinformowany o: możliwości uzyskania pomocy medycznej (65\%), możliwości uzyskania pomocy prawnej (48\%), możliwości dochodzenia odszkodowania od sprawcy (32\%), możliwości uzyskania pomocy psychologa (19\%). Dodatkowe środki bezpieczeństwa zaoferowano $16 \%$ ofiar, natomiast $20 \%$ ofiar oceniło zachowanie policjantów jako rasistowskie lub ksenofobiczne.

Kontrowersyjne jest odwołanie się do symptomów PTSD; zespół ten powinien zostać zdiagnozowany przez odpowiedniego specjalistę, a uczestnicy nie zostali poddani specjalistycznym badaniom (odpowiadali jedynie na pytania ankiety). Deklarowane przez nich objawy nie musiały mieć związku z byciem ofiarą przestępstwa (mogła wystąpić koincydencja $\mathrm{z}$ innymi zdarzeniami, również związanymi z krajami ich pochodzenia). $\mathrm{Z}$ raportu wynika, że u 58\% uczestników badania wystąpił co najmniej jeden objaw PTSD: stan czujności (25\%), nawracające myśli (25\%), unikanie wspomnień (20\%), nagłe reakcje emocjonalne (18\%), nerwowość, 
niepokój (18\%), unikanie czynności przywołujących wspomnienia (15\%), koszmary (13\%), powtórne przeżywanie (7\%). Kontrowersyjne jest również ustalanie stopnia depresji w tego rodzaju badaniach (bez udziału specjalisty, ocena na podstawie jednej rozmowy). Autorzy mierzyli depresję, jak enigmatycznie opisują, ,zadając pytania o objawy depresji, a także stosując wskaźnik nasilenia depresji” (s. 60).

Otrzymane w tym zakresie wyniki w naszej opinii odzwierciedlają metodologiczne problemy z konceptualizacją i operacjonalizacją niektórych zmiennych w przedmiotowych badaniach. Samopoczucie psychiczne nie było cechą istotnie różnicującą psychiczne funkcjonowanie osób będących oraz niebędących ofiarami przestępstwa z nienawiści (było nawet nieco lepsze u pokrzywdzonych). Samopoczucie psychiczne nie było jednak badane u wszystkich osób w tym samym czasie po zdarzeniu; wartość tej cechy była ustalana na czas badania. W grupie badawczej i kontrolnej podobny był poziom zaufania do instytucji (czyli kontakty z polskimi instytucjami nie miały negatywnego wpływu). Można to uzasadnić tym, że ofiara przestępstwa na podstawie swojego doświadczenia (jak i relacjonowanych jej doświadczeń innych osób, ewentualnie sposobu prezentowania instytucji państwa w mediach) wyrabia sobie określone oczekiwania wobec przedstawicieli państwa, którzy przyjmują jej relację. Doświadczenia badanych z odpowiednikami polskich instytucji $\mathrm{w}$ ich rodzinnych krajach mogły być gorsze. W porównaniu z wynikami w grupie badawczej stan zdrowia ofiar przestępstwa nie był gorszy. Nie było liniowej korelacji między poziomem zadowolenia z życia a faktem bycia ofiarą przestępstwa. Ciekawe były wyniki badań odnośnie do strachu przed przestępczością; przedmiotem różnic był wyłącznie aspekt behawioralny (uwzględniono również składnik afektywny, poczucie bezpieczeństwa $\mathrm{w}$ trakcie chodzenia w sąsiedztwie po zmroku, nie badano składnika kognitywnego ${ }^{17}$ ).

Wyniki pokazują, że doświadczenie przestępstw z nienawiści zwiększa skłonność respondentów do unikania pewnych miejsc, a nawet niewychodzenia po zmroku. Muzułmanie i osoby z Afryki Subsaharyjskiej często nie ujawniały elementów swojego wyglądu (osoby z Ukrainy nie różnią się wyglądem od Polaków). Autorzy raportu podkreślają, że

17 J. Błachut, A. Gaberle, K. Krajewski, Kryminologia, Gdańsk 2004, s. 450 n. 
zgłaszają przestępstwo przede wszystkim te ofiary, które mają zaufanie do adresata (instytucji i jej pracowników). Mogą postrzegać polskie instytucje w kontekście ich doświadczeń w rodzinnych krajach, które są zazwyczaj negatywne. Pomimo podniesionych zastrzeżeń o charakterze metodologicznym badanie dostarcza interesujących informacji na temat sytuacji psychologicznej ofiar niektórych przestępstw.

Sytuacja osób uczestniczących w sprawach sądowych w Polsce, w tym również świadków (będących często osobami pokrzywdzonymi), monitorowana jest od 2011 roku przez fundację Court Watch Polska. W Obywatelskim monitoringu sądów 2017/2018 ${ }^{18}$ można znaleźć wymowne dane statystyczne, a także opisy przykładów zachowań pracowników sądów wobec świadków. Analizowany raport obejmuje wyniki monitoringu prowadzonego przez 415 wolontariuszy w 147 sądach od 15 lipca 2017 do 16 lipca 2018 roku; uwzględniono 4696 obserwacji. W kontekście sytuacji ofiary przestępstwa-świadka w sądzie warto zwrócić uwagę na kilka analizowanych parametrów. W 92\% rozprawa odbyła się w wyznaczonym terminie; rozpoczęła się punktualnie w $44 \%$ przypadków, a w $23 \%$ przypadków pracownik sądu wyjaśnił stronom przyczynę zwłoki w rozpoczęciu rozprawy i przeprosił za opóźnienie. W 98\% sytuacji obserwatorzy uznali, że sąd równo traktował strony (w 4\% monitorowanych spraw obserwator uznał, że sędzia w stosunku do strony zachował się w sposób niekulturalny lub agresywny).

Przedmiotowy raport w ciekawy poznawczo sposób łączy dane ilościowe oraz jakościowe. W zakresie danych jakościowych opisuje konkretne przykłady z uwzględnieniem pozytywnych i negatywnych zachowań sędziów. Jedną z przedstawionych sytuacji jest wypowiedź: „Nie nie wiadomo. Rozprawa nie została wywołana, nikt nie wyszedł do oczekujących. Na wokandzie brak informacji o odwołaniu rozprawy" (s. 51 raportu). Wśród opisów pozytywnie opiniowanych zachowań sędziów znajdziemy takie przykłady, jak (s. 26 i 79): „Sędzia zadawał dużo szczegółowych pytań, był bardzo zainteresowany prowadzoną sprawą. Uzasadnienie było ciekawe i dobrze umotywowane”, „Sędzia w bardzo zrozumiały sposób prowadzi rozprawy, tłumaczy każdą kwestie na powszechni język”, „Sę-

18 Obywatelski monitoring sądów 2017/2018, https://courtwatch.pl/wp-content/uploads/FCWP2019_raport.pdf (dostęp: 30.09.2019). 
dzia była bardzo uprzejma i kulturalna względem zeznającego świadka [...]. Wielokrotnie dopytywała i ustalała, czy właściwie zrozumiała zeznania, aby poprawnie je zaprotokołować”. Z kolei przykładami negatywnie opiniowanych zachowań są (s. 28, 30, 76, 80): „Podczas rozprawy, w mojej ocenie, zdarzyło się wiele sytuacji, w których sędzia zwracała się do stron w sposób niekulturalny, silnie podniesionym głosem, wręcz momentami krzyczała”, „Podczas składania zeznań przez pokrzywdzonego, kilkakrotnie p. sędzia szeptała coś sędziemu po swojej lewej stronie, po czym cała ich grupka się śmiała. Wyglądało to na żartobliwe uwagi związane z pokrzywdzonym”, „Świadek nie wiedział, dlaczego został wezwany. Gdy świadek zapytał sędziego, czy chodzi o zakupy sprzed kilku lat, sędzia w sposób oburzony odpowiedział »To sąd ma zadawać pytania, a nie Pan «", „Do świadka, starszej siedemdziesięcioletniej kobiety [...] sędzia zwróciła się: "proszę wyciągnąć te ręce z kieszeni, trzeba przynajmniej udawać, że się szanuje wymiar sprawiedliwości«”, „Jednym ze świadków była kobieta w początkowym stadium ciąży, co sędzia szybko zauważyła - uprzejmie i z empatią zapytała: »czy świadek ma siłę stać podczas przesłuchania, bo jeśli nie, to możemy przynieść krzesło «". Raport niestety nie wyróżnia osób pokrzywdzonych przestępstwem. Dostarcza jednak informacji, które mogą być również interpretowane w kontekście obecności w sądzie ofiary przestępstwa, tym bardziej że nie ma podobnych danych odnośnie do zachowań prokuratorów i funkcjonariuszy policji.

\section{Gotowość osoby pokrzywdzonej do złożenia zawiadomienia o popełnieniu przestępstwa}

W kontekście podjęcia przez osobę pokrzywdzoną przestępstwem decyzji o złożeniu zawiadomienia o popełnieniu przestępstwa istotną kwestią jest rozpoznanie potencjalnych i istniejących w tym zakresie przeszkód. Wśród źródeł oporu przed zgłoszeniem sprawy organom ścigania istną rolę odgrywa sytuacja psychologiczna ofiary przestępstwa. W pracy z taką osobą należy zidentyfikować istniejące przyczyny niechęci do współpracy, a później zminimalizować ich znaczenie.

S. Hardy wyróżnia cztery rodzaje barier, których istnienie pozwala dokonać klasyfikacji przyczyn oporu osoby pokrzywdzonej przed doniesieniem o przestępstwie na: bariery strukturalne, bariery społeczne, 
bariery sytuacyjne oraz bariery indywidualne ${ }^{19}$. Przeszkody sytuacyjne są powiązane z kontekstem politycznym, ekonomicznym i społecznym. Sytuacja ekonomiczna kraju może skłaniać polityków do oszczędzania środków publicznych przeznaczonych różnym instytucjom zajmującym się przeciwdziałaniem i zwalczaniem przestępczości lub pomagającym ofiarom przestępstw. Może skłaniać do położenia nacisku na ściganie określonego rodzaju czynów zabronionych i przeznaczenie relatywnie niskich środków na ściganie innych. Część pokrzywdzonych może więc uważać, że nie ma sensu zgłaszanie pewnych czynów policji, ponieważ brakuje środków pozwalających na podjęcie odpowiednich działań w celu ujawnienia i ujęcia sprawców. Hardy podkreśla również, że źródłem barier strukturalnych mogą być prezentowane przez polityków narracje, w szczególności prezentowane przez nich w środkach masowego przekazu opinie na temat określonych grup społecznych, w szczególności imigrantów zarobkowych czy uchodźców politycznych, jak również mniejszości religijnych czy seksualnych. Narracje te mogą wpływać na postawy i zachowania pracowników instytucji publicznych, a także na ukształtowanie się przekonania u części osób pokrzywdzonych, że w sytuacji zgłoszenia przestępstwa nie uzyskają odpowiedniej reakcji organów państwa. Bariery społeczne są związane z funkcjonowaniem ofiary przestępstwa $\mathrm{w}$ określonych grupach społecznych, na przykład rodziny, przyjaciól, znajomych, oraz etnicznych i religijnych. W obrębie danej grupy mogą istnieć przekonania (oparte na doświadczeniach jej członków), że zgłoszenie przestępstwa nie zapewni odpowiedniej reakcji ze strony organów państwa. Hardy wspomina przykładowo o osobach niepełnosprawnych i mniejszościach seksualnych. W pewnych grupach, na przykład osób, które same często są sprawcami przestępstw, mogą funkcjonować normy grupowe, które wprost zakazują kontaktu $\mathrm{z}$ funkcjonariuszami policji $\mathrm{w}$ jakichkolwiek sytuacjach. W przypadku ofiar niektórych czynów zabronionych funkcjonowanie w zintegrowanej i opartej na zaufaniu społeczności może sprzyjać powierzeniu „wyrównania rachunków ze sprawców" osobom z tej grupy.

19 S. Hardy, Layers of resistance: understanding decision-making process in relation to crime reporting, „International Review of Victimology” 25, 2019, s. 302-319. 
Poziom barier sytuacyjnych w modelu S. Hardy obejmuje wiele czynników kontekstualnych oraz środowiskowych. Jednym z nich jest częstotliwość, z jaką osoba staje się ofiarą czynów określonego rodzaju czy przestępstw w ogóle. Może dojść do swoistej „habitacji”, osadzenia się przez określoną osobę w roli ofiary. Na przykład osoba, która często jest obrażana, może bagatelizować zachowania sprawców, albo ktoś, kto już w dzieciństwie doświadczył negatywnych zachowań innych osób, nie reaguje później na popełniane wobec niej czyny zabronione. Inne bariery sytuacyjne dotyczą relacji pomiędzy sprawcą a ofiarą czynu zabronionego, w szczególności gdy ofiara wie, że sprawca jest mściwy czy zachowuje się agresywnie. Jednocześnie może on być partnerem życiowym, współpracownikiem, sąsiadem, znajomym. Źródłem oporu przed ujawnieniem czynu zabronionego jest wtedy często obawa przed pogorszeniem sytuacji czy odwetem. Przeszkodami sytuacyjnymi mogą być również antycypowane problemy związane z: brakiem czasu niezbędnego do zgłoszenia czynu zabronionego, a później udziału w czynnościach procesowych (na przykład osoby opiekujące się dziećmi lub innymi osobami wymagającymi opieki, jak również osoby, od których wymaga się nieopuszczania miejsca pracy), transportem do miejsca zgłoszenia przestępstwa (osoby niepełnosprawne lub starsze), nieznajomością albo słabą znajomością języka (obcokrajowcy). Przeszkodą może być również obawa przed zgłoszeniem czynu zabronionego, gdy osoba ta sama narusza prawo (na przykład pracuje lub przebywa nielegalnie na terenie określonego kraju czy też została ofiarą w związku z własnym działaniem przestępczym).

Bariery indywidualne są związane z indywidualnymi cechami psychologicznymi ofiary przestępstwa, jak również z jej wiedzą, doświadczeniem i zinternalizowanym systemem wartości. Bariery te dotyczą na przykład osób, które w przeszłości były już ofiarami przestępstw, zgłosiły je i nie spotkały się z odpowiednią reakcją organów państwa (były sfrustrowane lub rozczarowane zachowaniami policjantów, prokuratorów, sędziów czy pracowników innych instytucji).

Sytuacja psychologiczna ofiary przestępstwa może obejmować wszystkie czynniki wskazane w modelu Hardy; te same elementy będą jednak inaczej postrzegane przez różne osoby w zależności od ich cech indywidualnych — odmienne będą u różnych pokrzywdzonych możliwości i sposoby radzenia sobie z tymi barierami. Dokonane przez funkcjo- 
nariuszy organów ścigania lub pracowników wymiaru sprawiedliwości rozeznanie sytuacji psychologicznej ofiary przestępstwa jest pierwszym etapem zmniejszania wpływu opisywanych barier. Może również przyczynić się do minimalizowania skutków wtórnej wiktymizacji.

\section{Zakończenie}

Pokrzywdzony nie tylko inicjuje postępowanie karne, ale najczęściej jest źródłem informacji, dowodów, które są podstawą przyjęcia określonej wersji przebiegu zdarzenia. W prawie 77\% przypadków wszczęcie postępowania karnego jest reakcją na złożenie zawiadomienia o popełnieniu przestępstwa przez pokrzywdzonego lub inną osobę (niedziałającą $\mathrm{w}$ imieniu jakiejkolwiek instytucji) ${ }^{20}$. Dlatego też gotowość ofiar przestępstw do zgłaszania faktu ich zaistnienia oraz złożenia relacji jest tak istotna odnośnie do zapewniania porządku prawnego.

W wyniku bycia ofiarą czynu zabronionego osoba fizyczna ponosi wiele negatywnych konsekwencji (wiktymizacja pierwotna) ${ }^{21}$. Należą do nich między innymi: poczucie winy, obrażenia fizyczne lub choroby somatyczne albo psychosomatyczne, koszty psychologiczne (lęk, agresja, symptomy depresji albo PTSD), zmiany w funkcjonowaniu społecznym (unikanie poszczególnych grup czy miejsc, utrata zaufania do określonych grup osób lub społeczeństwa jako całości), straty materialne (nie tylko dobra zabrane przez sprawców, lecz także koszty leczenia, rehabilitacji, terapii lub koszty związane ze zmianami w funkcjonowaniu na co dzień). Efekty te mogą być pogłębione ze względu na szczególne cechy osoby pokrzywdzonej (na przykład w świetle danych amerykańskich osoby niepełnosprawne były dwa i pół razy częściej ofiarami przestępstw niż osoby bez niepełnosprawności ${ }^{22}$ ). Znalezienie się w sytuacji ofiary przestępstwa ma cechy sytuacji psychologicznej. Jak wskazano, obejmuje ona aspekty nie tylko obiektywne, wspólne dla określonych rodzajów

20 J. Błachut, Problemy związane z pomiarem przestępczości, Warszawa 2007, s. 167 n.

21 J. Shapland, M. Hall, What do we know about the effects of crime on victims?, „International Review of Victimology” 14, 2007, s. 178 n.

22 Według danych opublikowanych w lipcu 2017 roku przez Departament Sprawiedliwości USA, obejmujących lata 2009-2015, https://www.bjs.gov/content/pub/pdf/ capd0915st.pdf (dostęp: 30.09.2019). 
czynów zabronionych czy cech zewnętrznych ofiary, lecz także subiektywne, zależne od cech psychologicznych oraz życiowego doświadczenia, indywidualnego postrzegania swojej sytuacji w kontekście popełnionego czynu zabronionego. Skuteczna pomoc ofiarom przestępstw, a jednocześnie zachęcanie ich do raportowania tej sytuacji i dostarczenia pełnej relacji odnośnie do przebiegu zdarzenia wymaga uwzględnienia przez organ procesowy subiektywnej sytuacji psychologicznej ofiary. Takie podejście może również złagodzić efekty wiktymizacji pierwotnej ${ }^{23}$ oraz zmniejszyć ryzyko wiktymizacji wtórnej (na przykład możliwości stosowania wobec ofiary przestępstwa kar porządkowych).

Ustalenie subiektywnej sytuacji psychologicznej osoby pokrzywdzonej przestępstwem wymaga odpowiedniego wyszkolenia funkcjonariuszy organów ścigania oraz pracowników wymiaru sprawiedliwości, jak również zmiany podejścia organizacyjnego. Funkcjonariusz policji rozmawiający z ofiarą przestępstwa powinien umieć rozpoznać i zminimalizować potencjalne źródła niechęci pokrzywdzonego do składania zeznań. Jednocześnie powinien dysponować odpowiednim czasem poświęcanie większej uwagi pokrzywdzonemu nie może się odbywać kosztem innych obowiązków i wiązać się z negatywną oceną ze strony przełożonych.

\section{Bibliografia}

Błachut J., Gaberle A., Krajewski K., Kryminologia, Gdańsk 2004.

Błachut J., Problemy zwiąane z pomiarem przestępczości, Warszawa 2007.

Hardy S., Layers of resistence: understanding decision-making process in relation to crime reporting, „International Review of Victimology” 25, 2019, s. 302-319.

Koper R., Stosowanie aresztowania wobec świadka w procesie karnym, „Prokuratura i Prawo" 2014, nr 5, s. 5-24.

Łukaszewski W., Koncepcje sytuacji trudnych: krok naprzód, czy krok wstecz, „Czasopismo Psychologiczne - Psychological Journal" 21, 2015, s. 33-38.

Mozgawa M., Glosa do uchwaty Sądu Najwyższego z dnia 20 września 2007 r. sygn. I KZP 26/07, „Prokuratura i Prawo” 2007, nr 12, s. 151-160.

23 Materiały z konferencji w Sztokholmie z 2012 roku, https://www.jaishankar.org/ Stockholm_Crim_Symposium12_summary.pdf (dostęp: 30.09.2019). 
Shapland J., Hall M., What do we know about the effects of crime on victims?, „International Review of Victimology" 14, 2007, s. 175-217.

Szpitalak M., Polczyk R., Czy ostrzeżenie może szkodzić? Wplyw ostrzeżenia na jakość zeznań świadka., „Z Zagadnień Nauk Sądowych” 86, 2011, s. 140-150.

Tomaszewski T., Człowiek i otoczenie, [w:] Psychologia, red. T. Tomaszewski, Warszawa 1979, s. 13-36.

\section{The willingness to report crimes within the context of a victim's psychological circumstances}

\section{Summary}

The authors rely on Tadeusz Tomaszewski's theory of psychological circumstance. The theory distinguishes between normal and difficult circumstances. A person's particular circumstances (for example a crime victim's circumstances) may be analyzed objectively and subjectively. The first of these assumes that elements of the situation are described from the outside (independently on the entity's psychological features and his or her experience). The second demands finding the situation from the entity's perspective. Law enforcement personnel should be able to determine a victim's subjective psychological circumstances and be able to adjust it to the situation. It allows to reduce a victim's resistance against crime reporting and allows the reduction of the impact of victimization and secondary victimization. This approach requires adequately trained stuff.

Keywords: crime victim's psychological circumstances, resistance against crime report, treatment of crime victims. 